\title{
THE POLITICAL PERCEPTION OF YOUTH IN BANGLADESH
}

Meheri Tamanna

Khabirpolash12@gmail.com

BRAC University Bangladesh

\begin{abstract}
Youth in politics can be a creative force, a dynamic source of innovation which in turn brings positive changes in political systems. But today's youth is neither deeply apathetic nor unconventionally engaged in mainstream politics due to its complex nature. This decreasing level of youth participation in politics not only endangers the quality of leadership but also jeopardizes the democracy of tomorrow. By using qualitative and quantitative data this study explored the trend of youth engagement and their disconnection with the current political systems. This study aimed to observe how the youth is unbundling the traditional concept of state power and identify the reasons for their non-engagement in politics which eventually challenges the political system of Bangladesh.
\end{abstract}

Keywords: Leadership, Political Perception, Young Population.

\section{A. INTRODUCTION}

The engagement of youth in politics can be a creative force, a dynamic source of innovation which can contribute to catalyze important changes in political systems. However, the youth's relationship with contemporary politics is complex and problematic ${ }^{1}$. Due to its complex nature, today's youth is neither deeply apathetic nor unconventionally engaged in mainstream politics. Current trends demonstrate that political involvement and participation of younger generations is declining in comparison to older citizens. This decreasing level of youth participation in politics not only endangers the democratic representativeness (quality of leadership) of today, but also jeopardizes the democracy of tomorrow. People's participation is widely accepted where citizen“s rights and expression can be focused. The engagement of citizens in the policy development of the state and government promises greater efficiency and effectiveness. Through this mechanism citizens can claim their rights based on equality rather than traditional notions of "norms, charity, benevolence or patronage". It is logical to assume that people are not willing to participate if their opinions aren't making the right differences. In South Asia particularly in Bangladesh after 11 years of autocratic ruling, democracy had finally been established in 1990 as a result of a mass upsurge with a core demand for participation. However, this is only rhetoric, while the reality remains that democratic decision making and participation of youth is still a far cry in Bangladesh.

1 Farthing, R. (2010). The politics of youthful antipolitics: representing the "issue"of youth participation in politics. Journal of youth studies,13(2), p. 181-195. 
Bangladesh is slowly but surely facing a breakdown of its existing democracy. Events such as the military soft coup in 2008 , followed by the breakdown of electoral processes in 2014. suggest this alarming transition. A unilateral change at recent times puts democracy at a prolonged halt. This change has triggered the opposition to boycott and has left the whole country polarized. The political and factional interests of individual leaders has manipulated the major political parties to be merged and fragmented ${ }^{2}$.

On the other hand, the quality of democracy and the low political participation of youth are continuously being questioned in this country. The reasons are various- political violence, endemic corruption in politics, empty promises by politicians, low trust on political parties has failed to appeal to the interest of urban and rural citizens. There has been a rise of an unhealthy culture of toll collection, vandalism, patronage of armed cadres, and hooliganism etc. Bangladesh is suffering a dysfunctional two-party system best put as the "Battling Begums" followed by an infantile democracy ${ }^{3}$.

This crisis of quality leadership, violence, rent-seeking, corruption, crime in national politics discourages young meritorious students to participate actively. In most cases political parties use young people as instruments in street politics or $r$ as foot soldiers rather than future leaders. In addition, with the downfall of democracy another issue simmering recently is the rise of political Islam. Surprisingly, after 2001 no major party has secured absolute majority and as a solution they have allied with other small parties for a coalition government The situation became worse when BNP allied with an extremist Islamic party for the thrust of power ${ }^{4}$.

\section{B. REASEARCH METODS}

This research aims to explore the trend of youth engagement and their disconnection with the current political trends by using the five factors developed by the writings of James Sloam (2007). Based on the premise of these factors we observe how the youth is unbundling the traditional concept of state power and identify the reasons for their non-engagement which eventually challenges the political system of Bangladesh ${ }^{5}$.

${ }^{2}$ Khan, S., Islam, A., \& Haque, I, 1996, Political culture, political parties and the democratic transition in Bangladesh, The University Press Limited, Dhaka, p. 90

${ }^{3}$ Beck, U, Freedom"s children", 2001Individualization: Institutionalized individualism and its social and political consequences, Sage, London, p. 13-25

${ }^{4}$ Qasem, A. "Five barriers to youth engagement, decision-making, and leadership in Yemen"s political parties", Briefing, 2013, Retrieved on $9^{\text {th }}$ of June 2015 from http://www.google.com.bd/url?sa=t\&rct $=j \& q=\&$ esrc $=$ s\&source $=$

${ }^{5}$ Mirazchiyski, P., Caro, D. H., \& Sandoval-Hernández, A. (2014). Youth future civic participation in Europe: Differences between the East and the rest. Social indicators research, 115(3), p. 1031-1055. 
To conduct the research ${ }^{6}$ both quantitative and qualitative methods have been used to answer the research questions. In order to answer main research questions and subquestions, primary and secondary ${ }^{7}$ data were collected. For background information an extensive literature study was performed using journal papers, books, magazines, newspapers and the internet. Besides, for more information, focus group discussions (FGD), In-depth interviews and observations were conducted ${ }^{8}$.

There are several areas in Dhaka with a high concentration of universities (Mostly Private)-Gulshan, Mohakhali. This study has been conducted on three selected locations Mohakhali and Dhaka University and Jahangir Nagar University, Savar, Dhaka. From each location, two selected areas were chosen for collection of data from the youth through survey, interviews and FGD which allowed the study to observe their behavioral and response mechanisms.

Before the main survey9, field visits to the selected study areas were conducted to have an idea about the concentration of young population and their characteristics. This also helped to determine the way for approaching the ultimate study samples. For Indepth interview and FGD an ice breaking session was conducted which allowed them to raise any relevant question and can share their opinion comfortably. From each area, three spots with high concentration of the target population was selected and from each spot around 10-15 respondents enrolled. Snow ball technique has been used to identify the respondents for FGD and In-depth Interview. In total 10 respondents participate in Indepth Interview and 15 respondents (5 in each group with similar characteristics) enrolled for FGD. In survey method total 138 young people aged $18-25$ has been participated. All respondents were informed about the purpose of the study and their verbal consent has been taken before taking interviews. All information was kept anonymous and confidential ${ }^{10}$. Usefulness is expected in this paper is to contribute knowledge in the field

${ }^{6}$ Sri Endah Wahyuningsih, 2014, Restorative Justice System-Di Tingkat Penyidikan Tindak Pidana Lalu Lintas, Tunas Puitika Publishing, Brebes, p. iv

${ }^{7}$ Anis Mashdurohatun, 2017, Hukum Kontrak, Ekonomi Syari'ah Dan Etika, Undip Press, Semarang, p. 56

${ }^{8}$ Bennett, W. L, 2008, Changing citizenship in the digital age, Civic life online: Learning how digital media can engage youth, Cambridge MA: The MIT Press, p. 12-14

${ }^{9}$ Gunarto, 2018, Fair Consumer Protection, Balanced And Proportional In A Fixed E-Commerce Agreement Based On Justice Value, Scholars Journal Of Arts, Humanities And Social Sciences, India, p. 605

${ }^{10}$ Diamond, L, Facing Up to the Democratic recession, Journal of Democracy, 26(1), 2015, p. 141155. Retrieved on $3^{\text {rd }}$ of March 2015 from http://muse.jhu.edu/journals/journal of democracy/v026/26.1.diamond.html 
of application of the law of absolute competence for the community of justice seekers as well as legal practitioners and students of law faculty. ${ }^{11}$

\section{RESULT AND DISCUSSION}

The purpose of this study was to understand the perception of youth on politics and the future influence of their perception. This article indicates that the urban youth population has a negative perception regarding current politics and they carefully avoid involvement. It has also been established that though they are not too interested due to the existing political isolation they still harbor strong patriotic feelings. Most participants want to see a change of scenario in the current politics. They want effective, dynamic but not rigid political engagement.

There is a large body of literature on youth participation in politics and political activities. Prior literature has established youth political participation to fall into two extreme paradigms- disengaged. However, little attention has been paid to the youth"s perception of politics. Youth in developing countries like Bangladesh believe that the old political structures are ill equipped to deal with the current issues that and there is an urgent need to reconceptualize the old politics ${ }^{12}$.

This study further demonstrates that the youth population in Bangladesh is not politically apathetic but isolated. This young population has indicated several problematic areas that require reformation. The following suggestions came out from the research findings:

Institutional changes requiring the political actors both local and government to put more effort into offering engagement opportunities for youth need to be made. The recent political culture needs to be modified. There has to be coordination among the political parties alongside mutual tolerance and integrity.

Clear conceptualization of political education emphasizing on good governance, proper democracy and consistency is required. The lack of knowledge is mainly attributed to the weak capacity building and poor planning of leadership programs. Some claim that the capacity building opportunities are intentionally facilitated to avoid leadership handover.

${ }^{11}$ Anis Mashdurohatun, Redyanto Sidji, Gunarto and Mahmutarom, Factors Causing Banking Cyber Crime in Indonesian, International Journal of Economic Research, Volume 14 Number 15 2017, p.295

${ }_{12}$ Sloam, J, Rebooting democracy: Youth participation in politics in the UK. Parliamentary affairs, 60(4),2007,548-567. 
Security is another issue that discourages the young generation to participate in Bangladesh politics. Political violence has victimized many members of political parties exposing them to attacks, kidnaps and eventual deaths. For example, Ilias, former lawmaker and organizing secretary of the BNP, and his driver Ansar Ali were kidnapped from Banani in the capital on April 17, 2012. They have remained missing ever since. Due to the likely probability of getting injured or losing lives; the young generation avoids political participation in Bangladesh ${ }^{13}$.

Lack of finance is another barrier to youth engagement which is component of a broader problem. It is related to poverty and specifically the lack of financial resources being a major limiting factor for forming a young and fresh political party. Almost every focus group across the country has mentioned the phrase, "politics is a luxury". The average Bangladeshi faces many a struggle everyday to ensure their livelihoods. They are left with little time to focus on politics. Moreover, there are large numbers of families where there are no breadwinners other than the youth member. Therefore, it is hardly possible for that youth to focus on politics ${ }^{14}$.

\section{Youth and politics in Bangladesh: the changing environment and the values}

Asia is constituted almost $60 \%$ of the total world population. Particularly in Bangladesh $46.7 \%$ (Aged 10-24) is young population (Population Reference Bureau, 2013). According to one estimate out of a total 150 million people in Bangladesh median age is 23.8 years (male) and 24.8 years (female) (Bangladesh Demographics profile, 2014). The proportion of youth in the Bangladesh has remained almost constant for the last ten years. This large number of youth can be of great advantage through their successful engage in politics. Our results demonstrated that why and how the youths feel disconnected from politics. The main attributes of this phenomena arises from the prevailing confrontational politics and the challenges of earning a livelihood which requires youth succor and leadership. The following sub-sections focus on the study participants"

${ }^{13}$ Chang, A, Youth Participation in East Asia. International Conference on Democratic Citizenship and Voices of Asia's Youth:Taipei, 2012, Retrieved on $28^{\text {th }}$ September 2014 from http://www. asianbarometer.org/ newenglish/publications/ workingpapers/no.73.pdf

${ }^{14}$ Bangladesh Demographics profile, Index Mundi, 2014, rethrived on $10^{\text {th }}$ of June 2015 from http:// www .indexmundi. com / Bangladesh /demographics_profile.html 
complex perception towards politics and existing difficulties that obstruct their effective participation in the political arena ${ }^{15}$.

The basic ingredient for youth political disconnection is their evident alienation from state. Their lack of accessibility to political parties, politicians, government actors has given rise to this phenomenon. Our study revealed that from over 138 students from both private and public universities only few are interested in national politics and a majority is reluctant to discuss it with their friends and family. The following table shows the percentage of youth interests (aged 18-25) in accordance to their political thoughts ${ }^{16}$.

\section{Table $^{17}$ 1: Interest in politics of youth $(\%)$}

\begin{tabular}{|l|c|c|c|c|}
\hline $\begin{array}{l}\text { Youth (age } \\
\text { 18-25) }\end{array}$ & Yes & $\begin{array}{c}\text { Usually } \\
\text { no }\end{array}$ & No & $\begin{array}{c}\text { No. of } \\
\text { Participants }\end{array}$ \\
\hline $\begin{array}{l}\text { Discuss politics with } \\
\text { friends }\end{array}$ & $54.82 \%$ & $33.33 \%$ & 11.85 & 138 \\
\hline Family & 27.94 & 48.23 & 23.83 & 138 \\
\hline $\begin{array}{l}\text { Interest in national } \\
\text { politics }\end{array}$ & 2.94 & 42.77 & $54.29 \%$ & 138 \\
\hline
\end{tabular}

In addition, In-depth interview over the youth reported that they are lack of connection with the conventional politics. In response to a question regarding their connection or disconnection in the Bangladeshi politics, one respondent Sharek (20) replies:

"I don"t think Bangladesh has a proper democracy. In most cases the politicians don"t pay attention to any of our demands. If they did, Bangladesh would have been in a far better place. Sometimes we share our views with our friends and family but that doesn"t amount to anything. All we can do is just expressing our opinions, which too gets taken away from time to time."

${ }^{15}$ Stoker, G, 2006, Why politics matters, Making democracy work, Palgrave, Macmillan, p. 971

${ }^{16}$ O'Toole, T., Lister, M., Marsh, D., Jones, S., \& McDonagh, A, Tuning out or left out? Participation and non -participation among young people. Contemporary politics, 9(1),2003, 45-61.

17 Population Reference Bureau, The world"s youth, 2013, retrieved on $12^{\text {th }}$ June 2015 from http://www.prb.org/pdf13/youth-data-sheet-2013.pdf 
Another participant Kheya (18 said), "As a woman, I find participation in politics very risky in Bangladesh. If I wish to participate or join any political activity my life might be at stake. The whole political environment is polarized into two groups. And I don"t see ethical operation of either. Have you seen the recent news? How politicians are trying to save their own children despite them being allegedly accused of murder. The print and electronic media is also polarized. So who can we really rely on for truth and justice?"

Mobilization being the third most significant factor includes politicians" support and responses. The politicians should actively engage themselves with this population to take their opinions into consideration and respond accordingly. Some suggest that there should be a direct mode of contact for the citizens to reach the politicians. The unhealthy political culture, political alienation and lack of youth empowerment negatively affect the behavior of the young generation. The study was conducted on two types of universities (public and private). Despite this fundamental difference the result shows that around $60 \%$ of both types of university students agree that politics can influence their personality. However, almost one third more public university in comparison to their counterpart believes political involvement has an impact on the young mind. There is a possibility that the students of public universities more actively participate in politics given these universities have specific students" political parties, a facility private universities don't provide $^{18}$.

In-depth knowledge about politics is a prerequisite for effective participation. Education is a key component for the accumulation of this knowledge. A lot of the politicians are not educated to say the least while some maybe lack of political knowledge despite adequate education. Common practice amongst Bangladeshi politicians includes power abuse; rent seeking, vandalism, toll collection and extortion. The study revealed that more than $69 \%$ of youth have feelings for their country but in contrast majorities (95\%) believe that politics is risky and unhealthy. Above $89 \%$ of youth reported that most political leaders and peoples representatives they are working only to fulfill their needs and politics is a game of uneducated, ghastly people ${ }^{19}$.

${ }^{18}$ Mahmud, S, Citizen Participation in the Health Sector in Rural Bangladesh: Perceptions and Reality. IDS Bulletin, 35(2),2004, 11- 18.

19 United Nations, Youth Political Participation and Decision-Making, 2012,Retrieved on 29th December from http://www.un .org/ esa/socdev/documents/youth/fact-sheets/youth-politicalparticipation.pdf 
$90 \%$ of the total participants don"t think of political leaders to have enough education or any knowledge of politics. More than $69 \%$ of youth have patriotic sentiments towards their country yet a vast majority ( $95 \%)$ stands by the notion of politics being risky and unhealthy. Above $89 \%$ of the inquired youth reported that most political leaders and people representatives work towards the fulfillment of personal goals. Majority has deemed the Bangladeshi politics as a game for the uneducated ghastly people ${ }^{20}$.

On the other hand, there is evidence to support the youth lacking the comprehension of the underlying complexities in politics. It also needs to be noted that the Bangladesh Bureau of Statistics (BBS) reported that the country's literacy rate of the population aged above 15 reached 59.82 per cent while the illiteracy rate is 40.18 . The literacy of women now stands at 55.71 percent (The Financial Express, 2015). Political knowledge refers to the awareness of the citizens regarding different national issues as well as holding accurate information regarding civic or other structural relationships. Even though literacy rate is quite high in Bangladesh there is a big gap between political knowledge/education and conventional education ${ }^{21}$.

\section{CONCLUSION}

The engagement of youth in Bangladesh politics is a crucial catalyst to bring changes in the political manner. The active and effective engagement of youth in politics could bring beneficial changes to the current political scenario. This study has the potential to uncover the youth political activity in terms of politics, democracy, voting and engagement. Additionally it hopes to enhance the understanding and will enlighten the stakeholder, governments and different actors about the development potentials and democratic credentials and will bring possible changes for effective democracy and good governance in Bangladesh. This may also contribute to the increasing body of politics and youth participation literature that goes beyond understanding youth participation in categorical terms. Government initiatives to involve youth in politics through youth leadership trainings and the ensuring of a secured political environment is the next step put our greatest asset to optimum utilization.

\section{BIBLIOGRAPHY}

${ }^{20}$ Ibid. 
Anis Mashdurohatun, 2017, Hukum Kontrak, Ekonomi Syari'ah Dan Etika, Undip Press, Semarang.

Bangladesh Demographics profile, Index Mundi, 2014, rethrived on 10th of June 2015 from http:// www .indexmundi. com / Bangladesh /demographics_profile.html

Beck, U, Freedom"s children“, 2001, Individualization: Institutionalized individualism and Its Social And Political Consequences, Sage, London.

Bennett, W. L, 2008, Changing citizenship in the digital age, Civic life online: Learning how digital media can engage youth, Cambridge MA: The MIT Press.

Chang, A, Youth Participation in East Asia. International Conference on Democratic Citizenship and Voices of Asia's Youth:Taipei, 2012, Retrieved on 28th September 2014 from http://www. asianbarometer.org/ newenglish/publications/ workingpapers/no.73.pdf

Diamond, L, Facing Up to the Democratic recession, Journal of Democracy, 26 (1), 2015. Retrieved on 3rd of March 2015 from http://muse.jhu.edu/journals/journal_of_democracy/v026/26.1.diamond.html

Farthing, R. (2010). The politics of youthful antipolitics: representing the "issue"of youth participation in politics. Journal of youth studies,13(2).

Gunarto, 2018, Fair Consumer Protection, Balanced And Proportional In A Fixed ECommerce Agreement Based On Justice Value, Scholars Journal Of Arts, Humanities And Social Sciences, India.

Gunarto, Anis mashdurohatun,etc, ABSOLUTE AUTHORITY OF HIGH COURT IN ADJUDICATING GRANT DISPUTE AMONG MOSLEM A Study of the decision of the Sumenep State Court Number: / Pdt.G/2014/PN.Smp, Man In India, 97 (24)

Khan, S., Islam, A., \& Haque, I, 1996, Political culture, political parties and the democratic transition in Bangladesh, The University Press Limited, Dhaka, p. 90

Mahmud, S, Citizen Participation in the Health Sector in Rural Bangladesh: Perceptions and Reality. IDS Bulletin, 35(2), 2004. 
Mirazchiyski, P., Caro, D. H., \& Sandoval-Hernández, A. (2014). Youth future civic participation in Europe: Differences between the East and the rest. Social indicators research.

O'Toole, T., Lister, M., Marsh, D., Jones, S., \& McDonagh, A, Tuning out or left out? Participation and non -participation among young people. Contemporary politics, 9(1), 2003.

Population Reference Bureau, The world“s youth, 2013, retrieved on 12th June 2015 from http://www.prb.org/pdf13/youth-data-sheet-2013.pdf

Qasem, A. "Five barriers to youth engagement, decision-making, and leadership in Yemen"s political parties", Briefing, 2013, Retrieved on 9th of June 2015 from http://www.google.com.bd/url?sa=t\&rct =j\&q=\&esrc=s\&source $=$

Sloam, J, Rebooting democracy: Youth participation in politics in the UK. Parliamentary affairs, 60(4),2007,548-567.

Sri Endah Wahyuningsih, 2014, Restorative Justice System-Di Tingkat Penyidikan Tindak Pidana Lalu Lintas, Tunas Puitika Publishing, Brebes.

Stoker, G, 2006, Why politics matters, Making democracy work, Palgrave, Macmillan, p. 971

United Nations, Youth Political Participation and Decision-Making, 2012,Retrieved on 29th December from http://www.un .org/ esa/socdev/documents/youth/factsheets/youth-political-participation.pdf 